\title{
East Asian Trade Cooperation versus US and EU Protectionist Trends and their Association to Chinese Steel Exports
}

\author{
Tanoos, James $\mathbf{J}^{1}$ \\ 'Purdue University, Indiana, USA
}

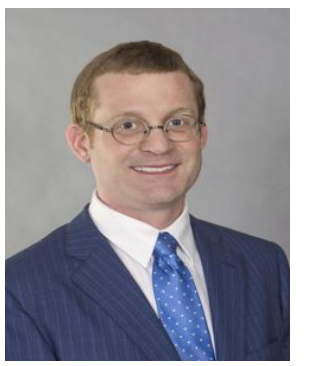

\begin{abstract}
The Asia-Pacific region has recently witnessed unprecedented trade cooperation, prompted especially by China. Successfully negotiated Chinese bilateral and regional Free Trade Agreements are now common, leading to greater rates of economic success for all involved parties, particularly Chinese exporters. FTA's are not limited to this region, though. The success of the Chinese pursuit of new FTA's has inspired economic rivals to pursue their own new FTA's. Many of these are developed countries which have a history of filing anti-dumping grievances with the World Trade Organization, many of which have been directed at China. This has led to heightened international trade tensions between China and non-Chinese FTA partners. For example, the US Trans-Pacific Partnership, a proposed FTA between the US and East Asian countries, intentionally did not include China. Many attribute the exclusion of China to the influence of US labor groups that have spearheaded anti-dumping grievances along with similar groups in other developed countries in an attempt to thwart China's efforts to increase their exports to these regions. The past few years have seen sharp increases in Chinese steel exports in particular, leading to heightened protectionist practices within the US and the EU. This study will assess the merits of these anxieties by analyzing the direction of Chinese steel to determine if Chinese steel is flowing more to their FTA partners or to developed countries without FTA's in place.
\end{abstract}

Keywords: Trade cooperation, Free trade agreement, Chinese steel, TPP, Manufacturing.

Citation | Tanoos, James J (2017). East Asian Trade Cooperation versus US and EU Protectionist Trends and their Association to Chinese Steel Exports. Asian Journal of Economics and Empirical Research, 4(1): 1-7.

History:

Received: 16 January 2017

Revised: 16 February 2017

Accepted: 24 February 2017

Published: 9 March 2017

Licensed: This work is licensed under a Creative Commons

Attribution 3.0 License (c) E

Publisher: Asian Online Journal Publishing Group
Funding: This study received no specific financial support.

Competing Interests: The author declares that there are no conflicts of interests regarding the publication of this paper.

Transparency: The author confirms that the manuscript is an honest, accurate, and transparent account of the study was reported; that no vital features of the study have been omitted; and that any discrepancies from the study as planned have been explained.

Ethical: This study follows all ethical practices during writing.

\section{Contents}

1. Introduction

2. Literature Review and Background

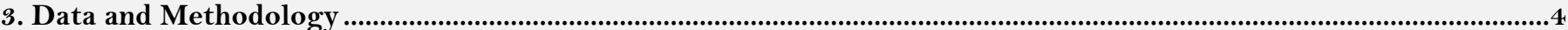

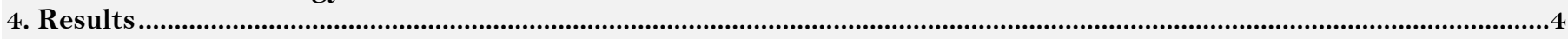

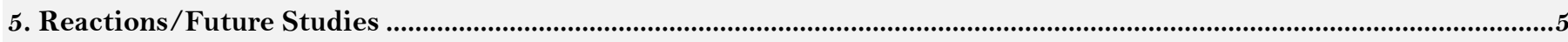

References. 


\section{Introduction}

Due to its record of economic success, Asia-Pacific trade cooperation continues to spread. However, with the increases in industrial exports originating from that region, tensions have escalated in developed countries, prompting increased anti-dumping grievances with the World Trade Organization (WTO). One focus of these complaints has been the steel industry, where Chinese exports have seen especially sharp increases in recent years.

With the increased salience of Free Trade Agreements (FTA's), especially new Chinese-prompted FTA's concentrated in the Asia-Pacific region, one might inquire whether these successfully negotiated Chinese FTA's are responsible for much of this steel export increase or if the increase is directed towards industrialized countries without Chinese FTA's in place. The anti-dumping claims may be misdirected if China's steel export increases are a result of selling more to their FTA partners. As such, this study will examine if these increases in Chinese steel production are being exported to their successfully negotiated FTA partners in order to assess whether there may be better means of complaining, such as negotiating better, more, or more favorable FTA's rather than filing antidumping disputes.

\section{Literature Review and Background}

The vast majority of economists point to overall economic gains as a result of decreasing international trade barriers and increasing trade cooperation (Krugman, 1997; Irwin, 2013; Kellenberg and Levinson, 2014). PREM (2015) called the elimination of trade barriers a "central" component of worldwide and domestic GDP growth. Geopolitical scholars point to the importance of access to markets as a result of decreased trade barriers for overall economic development, especially for underdeveloped countries (Akyüz, 2003; Mountjoy, 2007; Autor et al., 2013).

The accelerated trade cooperation concentrated in the Asia-Pacific region is a recent phenomenon (Zhang et al., 2007). and China in particular has taken the lead in prompting many of these trade negotiations and collaborations (Cass et al., 2004). It has been noted that this trend is the result of numerous successful FTA negotiations in the region and has led to a "chain-reaction" of unprecedented economic cooperation whereby countries are now trying to keep up with their neighboring countries in economic development (Ervine and Fridel, 2015). This was not always the case. The early 1990's were characterized by a regional economic rivalry between China and the Association of Southeast Asian Nations (ASEAN) trade group for industrial-based Asia-Pacific trade, an era characterized by limited trade cooperation and economic integration (Herschede, 1991; Chen, 2009). As recently as 2007, Hoadley and Yang (2007) described China's political leaders as "relative newcomers" in working toward Free Trade Agreements (FTA's).

The prestigious group of nations governing global trade, the World Trade Organization (WTO), was formerly an association composed of industrialized countries, but more recently, membership in this organization has been coveted by underdeveloped countries wishing to utilize the group's association to gain access to more markets, particularly for their manufactured goods. Numerous studies of China's WTO 2001 accession process uniformly noted the unprecedented increase in manufacturing-based trade, particularly after China was admitted as an official WTO member (Brandt et al., 2012; Cook, 2015). No other country's manufacturing trade has been examined in literature as closely as China's in recent decades (Chen, 2009). For instance, there have been numerous studies discussing aspects of Chinese export increases (Zhang et al., 2007; Amiti et al., 2014; Taylor, 2015). Brandt et al. (2012) commented that "China's import tariffs differed tremendously across industry in the earlier years, but converged to an almost uniform low level after WTO entry," and Allee and Scalera (2012) confirmed that "those who engage in the greatest amount of accession-driven liberalization experience the greatest trade increases from WTO membership, particularly in the years right after joining." This has been especially true of China.

China's intentional shift toward trade liberalization has not been limited to joining the WTO. In addition to successful transition to WTO membership, China has had success in negotiating regional Asia-Pacific FTA's (Baldwin, 2009). Recently, China has accelerated these FTA negotiations and has been a leader in the recent East Asian economic regionalism phenomenon of local trade cooperation (Cook, 2015). According to the Chinese Ministry of Commerce, China perceives FTA's as important components of not only integrating into the global economy but also furthering domestic reforms (Feng, 2012; Chinese Ministry of Commerce, 2015). Hoadley and Yang (2007) surmised that China utilizes "FTAs to open new markets."

While trade cooperation has historically focused on regional FTA's and WTO membership, an even more recent trend has been to negotiate FTA's with individual countries, which are often labeled "bilateral" or "extraregional" FTA's. Baldwin (2009) confirmed that industrialized nations "increasingly rely on bilateralism to open up foreign markets." It is becoming more common in East Asia, including China, for governments to formulate these bilateral FTA's (Zhang et al., 2007; Cook, 2015). These arrangements tend to go beyond the more historical crossregional FTA's such as ASEAN (Hoadley, 2007; Fora, 2014) and have increased between countries with mutual economic and/or political interests. For example, New Zealand and Chile have been economically profitable bilateral FTA partners with East Asian countries (Hoadley, 2007). These bilateral FTA's have been an up and coming strategy of East Asian governments (Hoadley, 2007; Zhang et al., 2007; Tosevska, 2010) in part because they take less time to negotiate.

As the Chinese negotiate new FTA's, there has been a coinciding rivalry in this pursuit. In the United States, the Obama administration in 2015 sought the Trans-Pacific Partnership (TPP), an FTA connecting the NAFTA trade partners to Pacific Rim countries (not including China) because of its potential to provide benefits beyond trade such as acting as a means of diplomacy and even as a counterweight to ASEAN (Wang, 2015). The Obama administration perceives FTA's as a means of expanding US exports and even diplomatic influence in the region (Cooper, 2011). This has not been a smooth process, though, as the United States Congress bitterly debated the TPP FTA during the first half of 2015. This FTA has been labeled "the most ambitious trade deal" since the signing of NAFTA (Granville, 2012) and is seen as a deal that boosts the Japanese influence in the region at the expense of China (Schlesinger et al., 2015). As a response, China has pursued and accelerated negotiations of its own new trade partnerships.

Manufacturing and industrial production tend to be the sectors in which developing countries can best gain economic development through FTA's (Akyüz, 2003; Mountjoy, 2007; Serfati, 2015). The development of heavy 
manufacturing industries for export has been a strategy of China since their WTO accession and has been called the "engine" of their economic growth (Zhao et al., 2012). Brandt et al. (2012) found positive domestic productivity benefits for Chinese manufacturers due to trade liberalization via WTO membership and FTA's. One economic sector which China has historically focused on as an important component of trade and global influence is the steel industry. Steel has always been a strategic economic sector for China and has provided the impetus for its fastgrowing industries in the 1990s (Hogan, 1999; Zhao et al., 2012). China has also historically seen steel production as a symbolic means of establishing itself in the global marketplace (Hogan, 1999; Song and Liu, 2013). Garnaut (2013) commented that "steel has been a central part of China's rapid growth story", and added that "developments in the steel industry... are central" to Chinese integration into the world economy.

Chinese steel exports have seen increases in total tons of steel exported. China's total crude steel production rose from just 39\% in the region in 2000 to $72 \%$ in 2014 (International Steel Statistics Bureau, 2015). From 20132014, China saw an increase in steel exports of over 50\% (translating to 93.78 million tons), while global steel output increased by only $1 \%$ (ISSB, 2015) and domestic Chinese steel consumption actually shrank by $3.4 \%$ (Davis, 2015). These numbers continue to skyrocket, as Wilson (2015) reported that in January 2015, China's steel exports increased by “a whopping 63\% from just last year's numbers."

Many believe that China is exhibiting an economic model called new trade theory (Fujita et al., 2015) an international trade strategy whereby a government uses economic tactics to build industrial bases in certain industries. Caliendo and Rossi-Hansberg (2012) found that liberalizing trade provides the exporter with more productivity than revenue. As such, China's increase in steel exporting might be attributed more to the goal of dominating world markets than the desire to make short-term financial gain.

Often, when countries experience such high rates of exporting in strategic sectors, importing countries retaliate with protectionist measures, which are international trade economic strategies by which a country restrains trade by various means, usually prompted by the fear of losing domestic output in manufacturing due to cheaper imports from underdeveloped areas (Singh, 2014). Recently protectionism has been on the rise, and there have been more signs of protectionist feelings in international trade during recent years (Blustein, 2009; Zhao et al., 2012; Roehrkasten, 2015). In both developing and developed countries, trade protection tends to be concentrated in politically sensitive areas such as labor-intensive manufacturing including steel (Wu et al., 2007; Chen, 2009; PREM, 2015). Wilson (2015) warned that in the current global marketplace, “China's excess sales create a very real threat" in the steel trade industry and noted the heavy focus on steel trade protectionism: "The global steel industry suffers from overcapacity in part because many countries make it a point of national pride to support a domestic steel industry." Since steel is also seen as a key industry for politically sensitive sectors such as the military, these sharp increases in Chinese steel exports have been particularly worrisome to developing countries (Mankiw, 2008; Sawyer and Sprinkle, 2015).

Partially prompted by the Chinese steel industry, protectionist feelings have accelerated, which in the past have translated into WTO-directed anti-dumping complaints. Dumping is a type of predatory pricing tactic affiliated with new trade theory in which a product (usually from an underdeveloped country) is sold at below the cost of production in another market in an effort to gain market share at the expense of profits (Raslan, 2009; HuertaGoldman, 2010; Cook, 2015). Trade protection demands by governments such as anti-dumping grievances in the steel industry have been common in history; in Yeager (1980) noted that "governments have become increasingly involved in steel production" for some time. In more recent decades, developed countries have been able to successfully negotiate these anti-dumping trade protection measures on Chinese goods. Anti-dumping grievances first gained momentum after China's WTO accession in 2001, when developed countries negotiated anti-dumping measures after China realized so much success in exporting steel (Wu et al., 2007; Chen, 2009; Zhao et al., 2012; Neumayer, 2013; Liu, 2014; Cook, 2015). In addition to prompting anti-dumping complaints, in 2001 the US requested the International Trade Commission to research the negative effects of steel imports on the domestic industry, resulting in three-year steel import tariffs levied in 2002 to protect the American steel industry, followed by requests to establish dispute panels in the WTO (Cook, 2015). The EU followed suit and placed tariffs on select imported steel products (Huerta-Goldman, 2010; Wilson, 2015). Zhao et al. (2012) surmised that the WTO has been in "defensive positions" recently with anti-dumping steel industry complaints from industrialized countries. As such, while an overriding goal of WTO membership is to limit trade disputes, it appears as if the opposite is happening.

As a result of these increases in Chinese steel exports since 2014, fresh outcries for trade protection have ensued. Serfati (2015) characterized the current state of global trade, including steel trade, as having "internal tensions among ... government actors". Mukherji et al. (2015) noted that "flooding the world with exports, spurring steel producers around the globe to seek government protection" prompted renewed calls in the EU and US for new trade protection measures. The European Steel Association prompted anti-dumping complaints with the EU in March of 2015 (Yap, 2015) and subsequently imposed anti-dumping duties on certain Chinese steel (Lian and Stanway, 2015).

As such, with the recent sharp increase in exports originating from East Asian heavy-industry sectors, most notably Chinese steel, an array of coinciding negative reactions in international trade will predictably continue based on the massive increases in Chinese steel exports (Akyüz, 2003; Neumayer, 2013; Cook, 2015). These reactions may be exacerbated by the Obama administration's negotiation of the TPP FTA that strategically did not include China and could serve to heighten tensions even further between the US and China, particularly in the steel industry.

While these protectionist reactions might be predictable, the question remains about whether they are misdirected. Often protectionist outcries are not the result of an attempt by a developing country to dominate global markets, potentially even at the expense of profits as new trade theory would outline, but may simply be the byproduct of a developing country's exporting without a broad FTA in place (Irwin, 2013). If a FTA was in effect, the massive increases in imports coming into a developed country may be offset by an equal amount of exports. There have been some studies detailing the relationship between FTA's and protectionism. One such study asserts that the existence of FTA's increases the likelihood of trade protectionism and even trade "discrimination" whereby 
antidumping actions are eliminated between FTA partners, leading to heightened tensions with non-FTA members (Prusa and Teh, 2010). One might inquire if these protectionist outcries in the form of anti-dumping complaints by governments are simply a caving-in to pressure from powerful anti FTA factions. An assessment of the direction of increased Chinese steel exports would shed some light on whether the anti-dumping grievances directed at steel have merit, or whether these sharp increases can be attributed to the recent record of successfully negotiated new Chinese FTA's. Perhaps governments should be pursuing more favorable negotiations with new FTA's to allow for better access to new markets rather than launching new rounds of anti-dumping grievances and tariff increases. An assessment of the directions of the sharp increases in Chinese steel exports would enlighten that inquiry.

\section{Data and Methodology}

A cross-sectional analysis of historical trends in recent Chinese steel imports related to new Chinese FTA's was the overall design for this study. Data related to Chinese steel exports were requested from the ISSB (2015) in the United Kingdom, which features data related to total tons of steel exported by China as well as importing countries from 2007-2014. Next, the study determined which of the steel importing countries constituted official Chinese FTA partners using information from the Chinese government's Ministry of Commerce. China has nineteen total trade partners from their FTA's as of August 2015 (CMC, 2015).

These partners are displayed in Table 1 below. The countries labeled with an "A" belong to the regional Chinese FTA of ASEAN. The table also depicts the year of the FTA, which was determined to be when the Ministry of Commerce claimed that the FTA "went into force" (CMC, 2015).

\begin{tabular}{l}
\multicolumn{1}{c}{ Table-1. Official Chinese FTA partners } \\
\hline BRUNEI (A-2005) \\
\hline BURMA (Myanmar) (A-2005) \\
\hline CHILE (2006) \\
\hline COSTA RICA (2008) \\
\hline HONG KONG (2003) \\
\hline ICELAND (2014) \\
\hline INDONESIA (A-2005) \\
\hline LAOS (A-2005) \\
\hline MACAO (2003) \\
\hline MALAYSIA (A-2005) \\
\hline NEW ZEALAND (2008) \\
\hline PAKISTAN (2007) \\
\hline PERU (2009) \\
\hline PHILIPPINES (A-2005) \\
\hline SINGAPORE (A-2005) \\
\hline SOUTH KOREA (2006) \\
\hline SWITZERLAND (2014) \\
\hline THAILAND (A-2005) \\
SIETNAM (A-2005) \\
Source: China's Ministry of Commerce
\end{tabular}

The next step consisted of discovering percentage changes in Chinese steel exports from year to year for both Chinese FTA partners and non-FTA partners. Between 2007 and 2014, four countries successfully negotiated and concluded a FTA with China: Pakistan, Peru, Costa Rica, and New Zealand. Switzerland and Iceland were also granted free trade status via a concluded FTA in 2014 and were excluded from this tabulation. The years in which the FTA "went into effect" for Pakistan, Peru, Costa Rica, and New Zealand were calculated as the first year of the FTA, and the years before were used in the non-FTA partners group.

\section{Results}

Of the top 10 destinations for Chinese steel in 2014, seven were FTA partners (South Korea, Vietnam, Philippines, Thailand, Indonesia, Singapore, and Hong Kong).

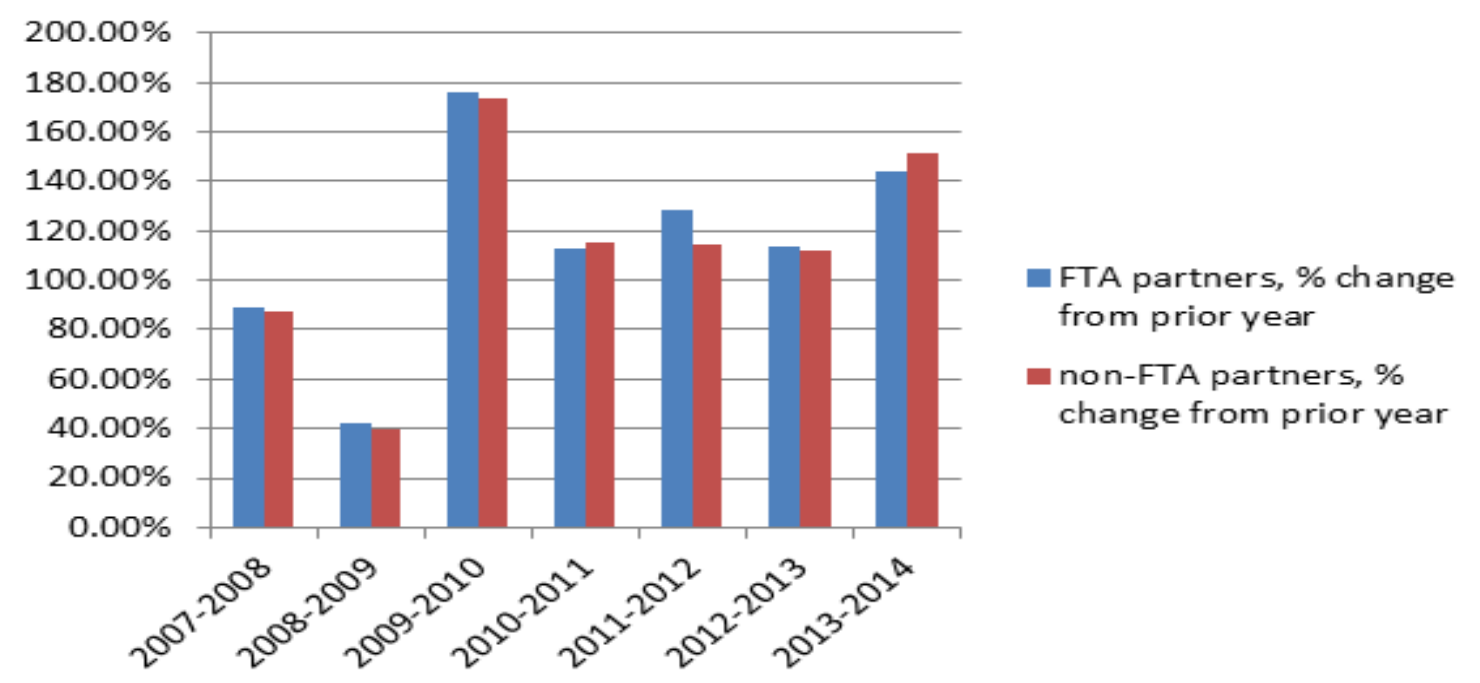

Figure-1. Year-to-Year Percentage Change in Chinese Steel Exports: FTA countries and non-FTA countries 
Figure 1 above displays the year to year percentage change in Chinese steel exports with both Chinese FTA countries and non-FTA countries. In five of the seven years, year-to-year changes in Chinese steel exports to FTA countries were higher than those to non-FTA countries.

Overall, steel exports to FTA partners increased more than steel exports to FTA partners at a $115.21 \%$ increase per year versus a yearly $113.41 \%$ steel export increase to non-FTA partners. However, the total tons of steel for FTA partners by 2014 was still $213,428,180$, versus 451,217,534 to non-FTA partners. Figure 2 below displays this Chinese steel export difference between FTA partners and non-FTA partners since 2007.

\section{7-2014}

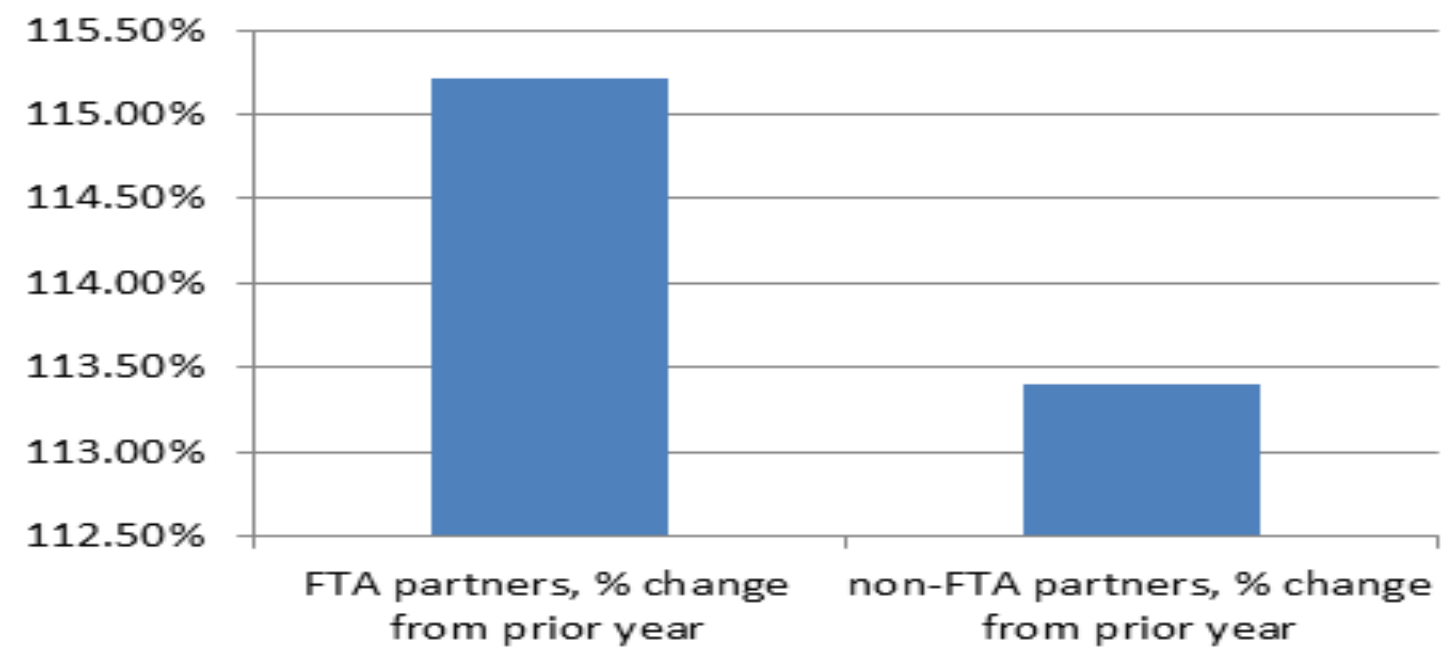

Figure-2. Difference Between Steel Exports: Average percentage of Chinese steel export change since 2007 between FTA partners and nonFTA partners

Next, the study analyzed bilateral FTA's versus regional FTAs. It appears as if Chinese steel exporting to ASEAN FTA partners increased at a higher rate per year $(119.52 \%)$ than the bilateral FTA per year rate (112.45\%). Table 2 below displays the yearly percentage of Chinese steel export change since 2007 between regional and bilateral FTA partners.

Table-2. Yearly percentage of Chinese Steel Export Change Since 2007 Between Regional and Bilateral FTA partners.

\begin{tabular}{l|l|l|l|l|l|l|l|l}
\hline & $\mathbf{2 0 0 8}$ & $\mathbf{2 0 0 9}$ & $\mathbf{2 0 1 0}$ & $\mathbf{2 0 1 1}$ & $\mathbf{2 0 1 2}$ & $\mathbf{2 0 1 3}$ & $\mathbf{2 0 1 4}$ & Avg. \\
\hline $\begin{array}{l}\text { ASEAN trade partners, } \\
\text { change from prior }\end{array}$ & $70.38 \%$ & $49.44 \%$ & $179.09 \%$ & $114.37 \%$ & $149.46 \%$ & $122.63 \%$ & $151.24 \%$ & $119.52 \%$ \\
\hline $\begin{array}{l}\text { bilateral trade partners, } \\
\text { change from prior }\end{array}$ & $103.48 \%$ & $39.53 \%$ & $173.29 \%$ & $114.30 \%$ & $114.06 \%$ & $104.25 \%$ & $138.25 \%$ & $112.45 \%$ \\
\hline
\end{tabular}

The "new" FTA partners during this timeframe (i.e., countries successfully completing a FTA with China from 2007-2014) included Pakistan, Peru, Costa Rica, and New Zealand. The years before were used in the non-trade partners group. Between these times, the year-to-year changes after the FTA went into effect for these countries was $139.22 \%$. Of course, this is higher than the year-to-year changes from non-FTA partners at a $115.21 \%$ increase versus a $113.41 \%$ change from non-FTA partners.

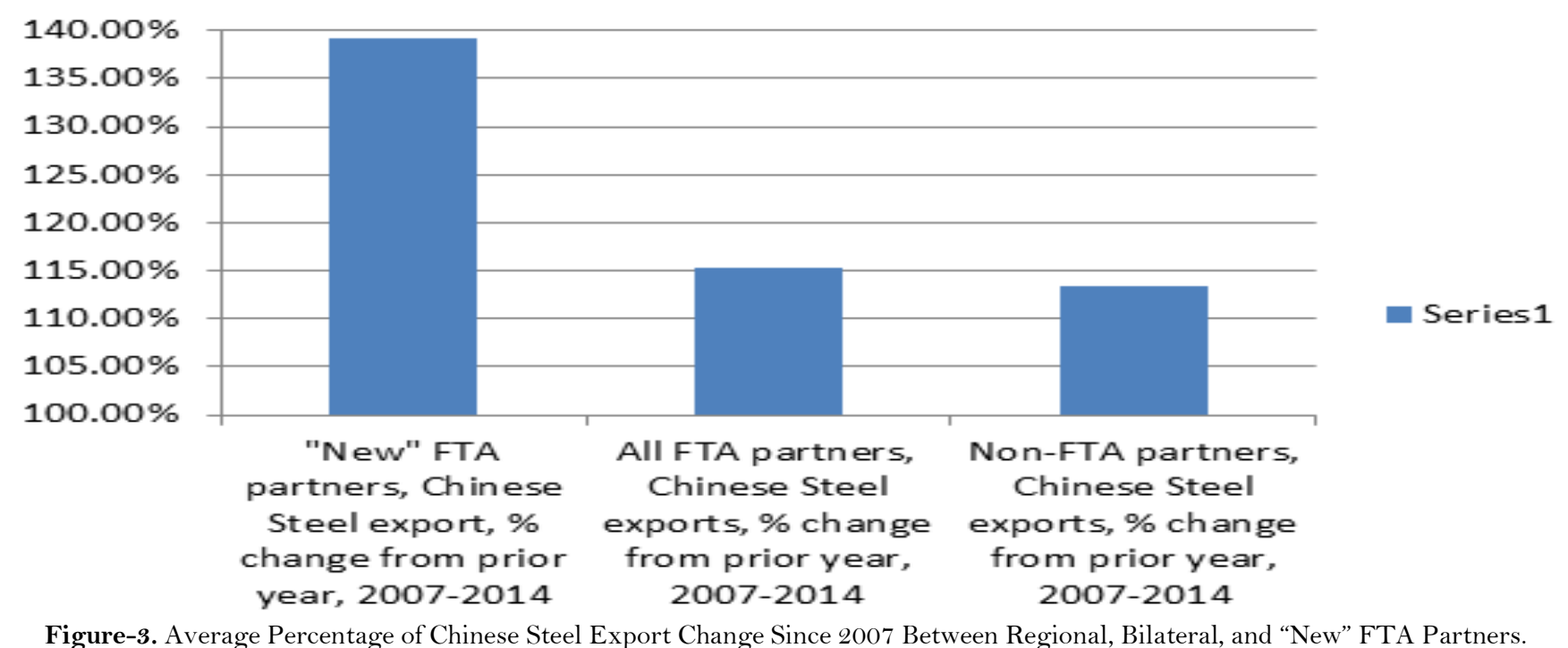

\section{Reactions/Future Studies}

There is a relative similarity in recent Chinese steel export increases between 2007-2014 attributed to both FTA partners and non-FTA partners. Since the anti-FTA factions in developed countries still claim that China is dumping steel into their markets, the TPP, which does not include China, could escalate tensions even further if Chinese steel exports continue such steep increases. The Serfati (2015) study characterized the current state of global trade as having anxieties between actors that are bound to intensify further. 
In the analysis of regional versus bilateral FTA's, it does appear that the regional Chinese trade partners have seen more steel exports than their bilateral partners. And perhaps more notably, with Chinese exports of steel increasing sharply to new FTA partners, a case may be made for the need to successfully negotiate FTA's with China. There may be some intentionality in China's pursuing recent FTA's, since there were such sharp increases in steel exports to these trade partners in the years immediately after the FTA was successfully negotiated. As such, there could be an economic rationale for China's non-FTA partners to negotiate new, mutually beneficial FTA's, especially if provisions in the recent FTA's contributed to the rise in steel trade. Another inquiry might be whether there is an equal increase in goods flowing from these new FTA partners to China.

Future studies might assess whether newly negotiated FTA's continue to be destinations for Chinese steel and whether these trade partners are increasing their exports to China. While many factions point to FTA's as having a net negative effect on developed countries, an assessment of the overall increases in exports rather than anecdotal evidence of the floundering of sectors or factories should be a main focus of anti-FTA factions.

Another subsequent study might analyze if the steel organizations with the highest productivity are making money or simply attempting to increase market share. Caliendo and Rossi-Hansberg (2012) found that liberalizing trade provides the exporter with more productivity than revenue; anti-dumping grievances would have more credence if many of these steel organizations are losing money in efforts to simply gain markets.

\section{References}

Akyüz, Y., 2003. Developing countries and world trade: Performance and prospects. Penang, Malaysia: Palgrave Macmillan Press.

Allee, T. and J. Scalera, 2012. The divergent effects of joining international organizations: Trade gains and the rigors of WTO accession. International Organization, 66(2): 243-276. View at Google Scholar | View at Publisher

Amiti, M., O. Itskhoki and J. Konings, 2014. Importers, exporters, and exchange rate disconnect. American Economic Review, 104(7): 19421978. View at Google Scholar | View at Publisher

Autor, D., D. Dorn and G. Hanson, 2013. The China syndrome: Local labor market effects of import competition in the United States. American Economic Review, 103(6): 2121-2168. View at Google Scholar | View at Publisher

Baldwin, R., 2009. Book review of termites in the trading system: How preferential agreements undermine free trade, by Jagdish Bhagwati. Journal of Economic Literature, 47(1): 180-181.

Blustein, P., 2009. Misadventures of the most favored nations: Clashing egos, inflated ambitions. New York: Public Affairs Publishing.

Brandt, L., J. Van Biesebroeck, L. Wang and Y. Zhang, 2012. WTO accession and performance of Chinese manufacturing firms: Ind ustrial organization and international trade and regional economies. Centre for Economic Policy Research. Discussion Paper No. 9166.

Caliendo, L. and E. Rossi-Hansberg, 2012. The impact of trade on organization and productivity. Quarterly Journal of Economics, 127(3): 1393-1467. View at Google Scholar | View at Publisher

Cass, D., B. Williams and G. Barker, 2004. China and the world trading system: Entering the new millennium. Pacific Affairs, 77(2): $313-315$.

Chen, C., 2009. WTO accession, foreign direct investment and international trade (Advances in Chinese Economic Studies). Camberley, UK: Edward Elgar Publishing.

Chinese Ministry of Commerce, 2015. China free trade agreement network. Retrieved from http://fta.mofcom.gov.cn/english/index.shtml.

Cook, D., 2015. Looking beyond accession: Challenges to implementing the world trade organization government procurement agreement in China. Journal of Public Procurement, 15(1): 93-1 16. View at Google Scholar

Cooper, W., 2011. Free trade agreements: Impact on U. S. trade and implications for US trade policy. Washington, DC: Congres sional Research Service.

Davis, A., 2015. China's steel exports rise as new taxation regime yet to bite. Reuters.

Ervine, K. and G. Fridel, 2015. Beyond free trade: Alternative approaches to trade, politics and power. London, UK: Palgrave Macmillan Publishing.

Feng, H., 2012. The politics of China's accession to the world trade organization: The dragon goes global. New York: Routledge Contemporary China Series Publishing.

Fora, A., 2014. Annals of the University of Oradea. Economic Science Series, 23(1): 86-92.

Fujita, M., I. Kuroiwa and S. Kumagai, 2015. The economics of East Asian integration: A comprehensive introduction to regional issues. Camberley, UK: Edward Elgar Publishing.

Garnaut, R., 2013. Book foreword to The Chinese steel industry's transformation by Ligang Song \& Haimin Liu. Camberley, UK: Edward Elgar Publishing.

Granville, K., 2012. The trans-pacific partnership trade deal explained. New York Times 11.

Herschede, F., 1991. Trade between China and ASEAN: The impact of the pacific Rim Era. Pacific Affairs, 64(2): 179-193. View at Google Scholar

Hoadley, S., 2007. Southeast Asian cross-regional FTAs: Origins, motives and aims. Pacific Affairs, 80(2): 303-325. View at Google Scholar | View at Publisher

Hoadley, S. and J. Yang, 2007. China's regional and cross-regional FTA overtures: In search for comprehensive national power. Pacific Affairs, 80(2): 327-348. View at Google Scholar | View at Publisher

Hogan, W., 1999. The steel industry of China: Its present status and future potential. Lanham, Maryland: Lexington Books.

Huerta-Goldman, J., 2010. Mexico in the WTO and NAFTA in a Nutshell: Litigating international trade disputes. Journal of World Trade, 44(1): 173-202. View at Google Scholar

International Steel Statistics Bureau, 2015. Asia- crude steel production- trade in steel. Retrieved from http://www.issb.co.uk/asia.html.

Irwin, D., 2013. Free trade under fire. Princeton, NJ: Princeton University Press.

Kellenberg, D. and A. Levinson, 2014. Waste of effort? International environmental agreements. Journal of the Association of Environmental and Resource Economists, 1(1/2): 135-169.

Krugman, P., 1997. Pop internationalism. Cambridge, Mass: The MIT Press.

Lian, R. and D. Stanway, 2015. Big China steel thrives, stoking export fears. Reuters.

Liu, J., 2014. Accession protocols: Legal status in the WTO legal system. Journal of World Trade, 48(4): 751-771. View at Google Scholar

Mankiw, N., 2008. Essentials of economics. 4th Edn., Cincinnati, OH: South-Western College Publishing.

Mountjoy, A., 2007. Industrialization and underdeveloped countries. Rutgers University, New Jersey: Aldine Transaction Publishing.

Mukherji, B., J. Miller and C. Yap, 2015. Why Chinese steel exports are stirring protests. Wall St. Journal.

Neumayer, E., 2013. Strategic delaying and concessions extraction in accession negotiations to the world trade organization: An analysis of working party membership. World Trade Review, 12(4): 669-692. View at Google Scholar | View at Publisher

PREM, A.S., 2015. Economic growth in the 1990s: Learning from a decade of reform. The World Bank Group.

Prusa, T. and R. Teh, 2010. Tilting the playing field: FTAs and the changing pattern of protection. VoxEU. org, 15.

Raslan, R., 2009. Antidumping: A developing country perspective. Alphen Aan den Rijn, Netherlands: Kluwer Law International Publishing.

Roehrkasten, S., 2015. Global governance on renewable energy: Contrasting the ideas of the German and the Brazilian governments. New York: Springer Publishing.

Sawyer, C. and R. Sprinkle, 2015. Applied international economics. New York: Routledge Publishing.

Schlesinger, J., M. Obe and M. Magnier, 2015. TPP: Momentum on trade deal bolsters U.S., Japan efforts to counter China. Wall St. Journal.

Serfati, C., 2015. The transatlantic bloc of states and the political economy of the transatlantic trade and investment partnership (TTIP). Work Organisation, Labour \& Globalisation, 9(1): 7-37. View at Google Scholar | View at Publisher

Singh, D., 2014. Southeast Asian affairs. Singapore: Institute of Southeast Asian Studies. 
Song, L. and H. Liu, 2013. The Chinese steel industry's transformation: Structural change, performance and demand on resources. Camberley, UK: Edward Elgar Publishing.

Taylor, T., 2015. Recommendations for further reading. Journal of Economic Perspectives, 29(2): 259-266. View at Google Scholar

Tosevska, K., 2010. Regional vs. Multilateral, bilateral vs. regional choices in the international trade for the republic of Macedonia. Conference Proceedings: International Conference of the Faculty of Economics. Sarajevo (ICES). pp: 1-11.

Wang, C., 2015. Obama's challenge to China: The pivot to Asia-U.S. China policy foundation, USA. Burlington, VT: Ashgate Publishing Company.

Wilson, S., 2015. Why Chinese steel exports are stirring protests. Wall St. Journal.

Wu, X., X. Liu and J. Du, 2007. Local firm's knowledge acquisition in the global manufacturing network: Evidence from Chinese samples. International Journal of Innovation \& Technology Management, 4(3): 267-281. View at Google Scholar | View at Publisher

Yap, C., 2015. China defends its steel exports. Wall St. Journal.

Yeager, M., 1980. Trade protection as an international commodity: The case of steel. Journal of Economic History, 40(1): 33-42. View at Google Scholar | View at Publisher

Zhang, Y., G. Zhang and H.G. Zhang, 2007. The prospects for China's free trade agreements. Chinese Economy, 40(2): 5-35. View at Google Scholar $\mid$ View at Publisher

Zhao, C., S. Lin and S. Bao, 2012. The Chinese economy after WTO accession. Farnham, Surrey, United Kingdom: Ashgate Publishing Company. 